South Asia Multidisciplinary Academic Journal

9| 2014

Imagining Bangladesh: Contested Narratives

\title{
Watching the International Crimes Tribunal from London
}

\section{Benjamin Zeitlyn}

\section{CpenEdition}

\section{Journals}

\section{Electronic version}

URL: http://journals.openedition.org/samaj/3711

DOI: 10.4000/samaj.3711

ISSN: $1960-6060$

\section{Publisher}

Association pour la recherche sur l'Asie du Sud (ARAS)

\section{Electronic reference}

Benjamin Zeitlyn, « Watching the International Crimes Tribunal from London », South Asia

Multidisciplinary Academic Journal [Online], 9 | 2014, Online since 22 July 2014, connection on 01 May 2019. URL : http://journals.openedition.org/samaj/3711 ; DOI : 10.4000/samaj.3711

This text was automatically generated on 1 May 2019.

\section{(c) $($ i) $(9)$}

This work is licensed under a Creative Commons Attribution-NonCommercial-NoDerivatives 4.0 International License. 


\title{
Watching the International Crimes Tribunal from London
}

\author{
Benjamin Zeitlyn
}

\section{Introduction}

1 In early 2013 the International Crimes Tribunal (ICT) in Bangladesh began sentencing alleged war criminals from the country's 1971 Liberation War. ${ }^{1}$ The trials, ensuing protests and counter protests dominated the news and conversations in Bangladesh and among British Bangladeshis in London. In London the debate was polarised and revealed newly energised political fault lines. Suddenly everyone was talking about Bangladeshi politics, new websites sprang up and social media was full of debate and comment on Bangladesh. Discourses emanating from London were a direct challenge to dominant discourses on current affairs in Bangladesh and the events of 1971. A lot of these subjectivities were also associated with particular forms of Islamist political activity that have emerged in London in recent years.

2 Through an examination of responses to the ICT, and the associated protests in Shahbagh and Shapla Chottor, this article describes the ways that politics in Bangladesh is regarded in London. By highlighting responses of people in London and connecting these with socio-economic and political events, the paper makes two connected arguments. The first is that the influence of Islamist movements can be seen in many responses of British Bangladeshis. This involves positionality towards events formed through the application of Islamist ideas to developing events, what DeHanas (2013b) refers to as 'elastic orthodoxy', and tools and approaches for engaging with dominant discourses. Experiences of British Muslims during the 'War on Terror', pervasive Islamophobia and representations of Muslims in mainstream media, have encouraged a critical approach to dominant discourses and narratives among British Bangladeshis. This has influenced the methods used to challenge dominant discourses about 1971 and recent events in Bangladesh. The second argument is that events in Bangladesh have led to a surge of 
interest in Bangladesh and in 1971 as a historical event among British Bangladeshis. Although it is difficult to quantify either the relative popularity of different discourses among a large and diverse group of people, or change over time, the recent emergence in London of on-line activism supporting a particular political position, is easier to evidence.

Transnational activities have long been identified as a site of diasporas politically engaging in the politics of their homeland. Technology has played a key role in facilitating diaspora engagement in politics (Vertovec 1999). Vertovec (1999) notes that diaspora political engagement takes many forms and positions, such as cosmopolitan, nationalist, anti-nationalist and reactionary ethno-nationalism. Østergaard-Nielsen (2003) reviews approaches to understanding transnational political activity, and distinctions made by authors between 'broad' and 'narrow', 'core' and 'expanded' modes. The narrow/core modes of activity indicate serious, regular activity, whereas the broad and expanded modes indicate occasional engagement. Østergaard-Nielsen argues that transnational political orientation is linked to the type of migration, the length of stay and migrants' structural position in the destination country. However, these patterns shift over time as transnational orientations replace migrant subjectivities and the receiving country's political influences exert their influence.

Østergaard-Nielsen explains how, when opposing a state that is allied to the destination country, transnational political actors appeal to international organisations such as the UN or NGOs. Transnational political networks seek to co-opt NGOs at national and international levels. These strategies not only adapt to the local political environment, but also adopt and deploy Western liberal norms of democracy and human rights. Transnational political activists can often act with freedom that would not be tolerated in their countries of origin, and consider themselves as having access to objective sources of information unavailable in the country of origin. However, it is not always clear to what extent these transnational networks represent groups in the country of origin (Østergaard-Nielsen 2003). Many of these patterns of political activity are observable in the responses of British Bangladeshis to recent events in Bangladesh.

5 This article is based on a series of interviews, participation in public meetings about Bangladesh and data drawn from websites and social media. Focusing on website and social media activity illustrates the way in which transnational engagement by British Bangladeshis has emerged and taken shape. Perhaps moving from occasional, broad interest to regular, narrow engagement, the analysis focuses on five websites and their associated social media accounts. These are summarised in the table below. All the sites were set up in spring 2013, several using easy-to-use Wordpress software. The websites are either registered in London or use popular website hosting services such as GoDaddy and Identity Protect to hide the website creator's identity. The websites provide no identifying names, organisations or addresses, and articles published on them are usually anonymous.

Table 1. British Bangladeshi Political Websites 


Table 1. British Bangladeshi Political Websites
\begin{tabular}{|l|l|l|l|l|l|l|}
\hline \multicolumn{1}{|c|}{ Website name } & $\begin{array}{l}\text { Registered } \\
\text { in }\end{array}$ & Date & Twitter account & First tweet & Facebook account & $\begin{array}{l}\text { Joined } \\
\text { Facebook }\end{array}$ \\
\hline www.Savebangladesh.org.uk & London & $25 / 03 / 2013$ & @savebdesh1 & $06 / 04 / 2013$ & https://www.facebook.com/savebdesh & $26 / 03 / 2013$ \\
\hline www.progressbangladesh.com/ & GoDaddy & $02 / 03 / 2013$ & @ProgressBangladesh & $16 / 02 / 2013$ & https://www.facebook.com/progressbangla & $14 / 02 / 2013$ \\
\hline www.feb28.info & London & $06 / 03 / 2013$ & @Feb28info & $04 / 05 / 2013$ & https://www.facebook.com/Feb28info & $06 / 03 / 2013$ \\
\hline www.bangladeshcrisisgroup.com & London & $28 / 09 / 2011$ & - & - & - & - \\
\hline www.Deshrights.org & GoDaddy & $28 / 02 / 2013$ & @DeshRights & $17 / 07 / 2013$ & - & - \\
\hline www.khichuri.org & $\begin{array}{l}\text { Identity } \\
\text { Protect }\end{array}$ & $13 / 02 / 2013$ & - & - & https://www.facebook.com/TheKhichuri & $26 / 02 / 2013$ \\
\hline
\end{tabular}

7 Interviews were conducted with twelve London-based British Bangladeshis to identify and understand discourses. Seven of these interviews were conducted in person and five by e-mail. To reflect a range of experiences and perspectives, the sample was selected purposely to include people thought to epitomise each of the main political positions in Bangladeshi politics, which are described below (Lewis 2011, Ali 2010, BX 2013). Eight members of the sample were born in the UK and four in Bangladesh. However, of those born in Bangladesh, two came to the UK in early childhood. The sample contained both men (7) and women (5), and ages ranged from in their twenties to fifties.

The paper is the result of discussion and debate, rather than a funded research project. As a small qualitative study, the sample and discussion used here are not intended to be representative. The interviews are used to identify discourses rather than comment upon the prevalence of one set of beliefs over another. The paper reports on English language blogs and press, and responses of British Bangladeshis to Bangla material. The focus is upon contemporary British Bangladeshi subjectivities in London, so it focuses on trends in social media and debate rather than trying to capture everything that is happening. Due to the fast moving nature of events in Bangladesh, the research also represents a moment in time which may be eclipsed by further developments.

\section{Background}

Bangladesh and British Bangladeshis are what Anderson (2006) characterises as 'imagined communities'. Gupta (2007) describes how Bengali intelligentsia, such as Rabindranath Tagore, deployed the notion of 'desh' (country, land or homeland) in the nineteenth century to unify Bengalis and connect them with a particular geography, in resistance to the colonial division of Bengal. Influenced by European ideas of nationhood but combining these with an emerging Bengali tradition, desh was used as a way of transcending geographical and social boundaries to create a nation (Gupta 2007: 182). Bangladesh was imagined based on these cultural roots and a shared language, which became a symbol of resistance to the Pakistani government in Bangladesh's independence struggle.

The 'International Crimes Tribunal' in Bangladesh refers to the trial of a group of men alleged to have committed war crimes during Bangladesh's independence struggle in 1971. Bengalis in East Pakistan fought against a Pakistani military regime that sought to prevent the implementation of the 1970 election results. During the nine month long war, according to one estimate, half a million people died (Curlin et al. 1976). Millions of people fled across the border to India, and many thousands of women were raped. The Pakistani military and their local allies specifically targeted Bengali intellectuals and Hindus and rape was used as a weapon of war (Linton 2010, Ali 2010: 51). Histories of horrors of the 
war and the eventual victory of the Mukti Bahini (freedom fighters) have become an integral part of nationalism in Bangladesh.

The Pakistani military formed auxiliary units of collaborators whose members have become known as Razakars. They are associated with many of the worst atrocities committed in the war (Linton 2010: 198, Lewis 2011:71). Members of these groups and the political party Jamaat-e-Islami are alleged to have participated in the murder of intellectuals (Linton 2010: 199). This is the dominant discourse on Bangladesh and 1971, one that is central to the construction of nationalism in Bangladesh and particularly to the Awami League party, which led the liberation movement. A number of studies, such as Bose's work on the war (2011a, 2011b), have challenged these discourses and accounts of the scale and nature of atrocities in 1971. Debates centre around issues such as the use of the word 'genocide' to describe Pakistani military atrocities and on the number of people killed in the war.

The legacy of this struggle is an Awami League party that sees itself as the party of the independence struggle, as a secular Bengali nationalist party. The main opposition to the Awami League is the Bangladesh Nationalist Party (BNP) who stress a Bangladeshi nationalism that combines Bengali and Islamic identities and Islamist political groups such as Jamaat-e-Islami who believe in a greater role for Islam and Shariah (religious law) in politics and society (BX 2013). Jamaat-e-Islami are the largest Islamist party in Bangladesh and have in the past been in government in coalitions with both other major parties. The party was banned from participating in the recent elections in Bangladesh on the grounds that it opposed both secularism and the formation of Bangladesh.

Nationalism in Bangladesh draws on the Liberation War as a powerful and traumatic mythology of the nation's birth. The shared cultural roots, language and history are important components of nationalisms everywhere and of the way Bangladesh is imagined today (Anderson 2006: 44). Nationalism, as Renan (1992 [1882]) says, involves both shared histories and shared forgetting (Hylland Eriksen 1993). The Liberation War, Mukti Bahini, and the role of Jamaat-e-Islami are part of the national mythology, and much eulogised in books, print media and film in Bangladesh. However, the shared history and shared forgetting about the events of 1971 are contested and so too, as a result, is nationalism in Bangladesh. To use Anderson's terms, the community that is imagined by competing groups does not extend the 'deep horizontal comradeship' to all who now count themselves as Bangladeshi (Anderson 2006: 7). As we will see, this turbulent history and partisan political scene has an enduring impact upon current events in Bangladesh and the way these are regarded in London. New communities, new media and new mythologies challenge dominant discourses.

\section{British Bangladeshi politics and the Umma}

There were 447,201 British citizens of Bangladeshi origin recorded in the British Census in 2011, 50\% of them lived in London and $18 \%$ in Tower Hamlets (ONS 2012). The proportion of British Bangladeshis who do not live in Tower Hamlets or inner London appears to be increasing. British Bangladeshis are a relatively deprived group in the UK. More than one in three live in a deprived area (Jivraj \& Khan 2013). Over half of British Bangladeshi children live in poverty (Platt 2009). 68\% of British Bangladeshis live in lowincome, often overcrowded households and rely more on benefits than any other community (Ofsted 2004: 5). One manifestation of this disadvantage, until recently, was 
relatively low average scores in examination results. This, however, is changing. By 2012/13 British Bangladeshi performance at GCSE was higher than the national average. This is part of a trend which has seen the proportion of British Bangladeshi pupils achieving five A-Cs in GCSEs rise from below 20\% in 1992 to 85\% in 2013 (The Economist 2007, Department for Education 2014).

Many analyses of British Bangladeshis in London comment upon the divisions between secular groups and Islamists, between Sufi or Barelvi Muslims linked to the Brick Lane Mosque and what some observers call 'revivalist Islam' or 'new Islam' associated with a range of Islamist ideas, including those of Jamaat-e-Islami in the nearby East London Mosque. Accounts illustrate the extent to which various Islamist groups have grown in popularity and influence among young British Bangladeshis. These divisions take on generational aspects (with British born generations embracing Islamist movements) and influence political positionality (Gardner \& Shukur 1994, DeHanas 2013a, 2013b, Alexander 2013, Glynn 2002, Eade \& Garbin 2002, Hussain 2007, Kibria 2008, Rozario 2011, The Economist 2013c). While 'revivalist' or 'new' Islam are widely used in academic literature to describe these movements, they are not terms that British Bangladeshis use regularly, so this paper uses the term 'Islamist' to refer to groups that seek a central role for Islam in politics.

Sayyid (2000) connects rising Islamic identification with two processes of 'decentring', the decentring of the west and the decentring of the peripheral nation state. This describes British Bangladeshis, in whom attachment to the idea of Bangladesh and the contested histories that have built up around 1971 is not as strong as it is among many who have grown up in Bangladesh. British Bangladeshis have not been so involved in the shared histories and processes of imagining through the media and education in Bangladesh that have created Bangladesh as a nation. Accounts of young British Bangladeshi views of Bangladeshi politics and 1971 from the years immediately after 9/11 report it being seen as 'irrelevant' and a 'joke', rejected for being so corrupt (Glynn 2002, 2006). This group has also become ambivalent about Britain due to experiences of Islamophobia and racism and opposition to British foreign policy in the 'War on Terror'. These rejections of/by nations and nationalisms emerged in a mutually reinforcing way with Islamist groups.

Eade and Garbin (2002) describe how younger British Born Bangladeshis have a greater tendency to reject Bengali nationalism and orient their interest towards the notion of an Islamic Umma (community) (Eade \& Garbin 2002: 139, Begum \& Eade 2005). New media on the internet and television channels help to create this transnational community and sense of belonging to a global Islamic community (Kibria 2008). The popularity of Islamist subjectivities in London has been set within a social and political context of fevered interest in and prejudice against Muslims in the years after 9/11. Negative portrayals of Muslims in the British media contributed to this and turned many British Muslims away from mainstream media, encouraging a search for alternative sources of information to challenge dominant discourses (Ahmad 2006).

DeHanas (2013a) describes revivalist Islam as 'deculturated', so that it is seen as 'pure' and timeless, without the syncretic influences of 'Bengali culture'. The strength and popularity of these ideas represent a victory for the East London Mosque's Islamist influenced interpretation of Islam among British Bangladeshis (DeHanas 2013b). The idea of 'elastic orthodoxy' DeHanas (2013b) describes how, influenced by the East London Mosque and other institutions, young British Bangladeshis employ local interpretations of Islam strategically in new contexts. It is this elastic orthodoxy that characterises many 
British Bangladeshi responses to recent events in Bangladesh. The next three sections examine reactions to the ICT, Shahbagh and Hefazot-e-Islam ${ }^{2}$ to illustrate these issues.

\section{The International Crimes Tribunal}

19 The International Crimes Tribunal (ICT) was set up by the Bangladeshi government in March 2010, based on an amended version of the International Crimes (Tribunals) Act of 1973 to try those accused of crimes from the 1971 war (Linton 2010). The ICT has been dogged by controversy since The Economist Magazine revealed that senior judges had been corresponding with advisors abroad and members of the government about the cases (The Economist 2012, 2013a).

Critics of the ICT question its motives, its existence, those who it is prosecuting and the processes of the tribunal. They accuse the government of using it to settle political scores (Jalil \& Rahman 2011, Islam 2011). Other critiques centre on the debate over whether the accused are 'small fish' and the perpetrators of the worst crimes are either dead or in Pakistan (The Economist 2012, Islam 2011). Information about the ICT on the " SaveBangladesh' website exemplifies these critiques:

The current Awami League government established the 'International Crimes Tribunal' to try people they accused of committing crimes during 1971. No Pakistanis have come before the court, nor have any ruling Awami League leaders who supported the Pakistan-side during the war, or even those who publicly committed war crimes after the war. The only people in the dock are those belonging to the Jamaat-e-Islami and the Bangladesh National Party (Save Bangladesh 2013a).

21 Another critique does not question the motives or targeting of the ICT but is concerned about due process in the way the tribunal has operated. This trend criticises the standards of evidence and restrictions on the defence in the tribunal (The Economist 2012, Bergman 2012). Websites such as Feb28 host detailed critiques of the ICT by defence barristers:
Abdul Quader Mollah was convicted following a highly controversial trial in which the Presiding Judge was removed following the resignation of the disgraced Chairman as a consequence of the 'Skypegate' scandal. The defence were prevented from calling witnesses and the case was promptly closed by the Tribunal and rushed to judgment. Both the Tribunal and the Supreme Court have failed to apply the law as it stood in 1971 and took judicial notice of contentious facts that were not in evidence. The defence were also prevented on numerous occasions from having privileged communications with the accused. The countless defects in the trial process and the numerous errors in law were so severe that they invalidate the entire judgment and any conviction amounts to a miscarriage of justice (Feb28 2013a).

Supporters of the ICT argue that it is necessary to continue the work that Mujib started but could not complete-to seek justice for the collaboration and war crimes committed during the war (Alam 2013)-and that it provides an opportunity for closure (Murshid 2013). However, the ICT is perceived by its critics not as a national process for justice and closure but as a political process to destroy and discredit Jamaat-e-Islami and even Islam itself (Islam 2011, Jalil \& Rahman 2011). What was supposed to be a national process has become a party political issue. Political divisions are represented in London. Some interviewees perceived the ICT as having been a success so far, free from political interference, but perhaps poorly publicised: 
So far the trial has gone without any kind of political involvement, but the process has not been managed well politically. The government should have given the PR side more thought (male, 33, migrated to London as a child).

Others highlighted the 'indoctrination' that had added to the problems of establishing the 'truth' of historical events. By this they referred to the dominant narratives on 1971 that are so integral to nationalism in Bangladesh. This respondent felt that the ICT was necessary but had been poorly run:

What do you think about the Bangladesh War Crimes Trial and the issues involved? The trial should have taken place a long time ago, should have happened 40 years ago. Now indoctrination for 40 years has made things worse. Bangladeshis need to have closure on the issue but what has happened so far will not bring the matter to a close.

How do you think the trial has gone so far?

The trial so far has been terrible. We don't know how to undertake a fair trial, how to conduct a fair trial. Gulam Azam and Sayedee ${ }^{3}$ are becoming shahids (martyrs) (female, 28, born in London).

Others felt that the ICT itself was a grave injustice, used for political reasons and violated existing legislation:

It is politically motivated and is a witch-hunt. This is a travesty of justice. There are three issues involved. 1. Oppress the political opponent 2. Try to gather mass support by using freedom fighting sentiment. 3. No intention to try actual war criminal because tri-country Delhi treaty ${ }^{4}$ will not allow it (male, 29, born in Bangladesh).

The ICT has become a contentious political issue, which has led to three main types of violence in Bangladesh. Islamist activists associated with Jamaat-e-Islami and their student wing, Islami Chhatra Shibir, have been accused of attacks against religious and ethnic minorities (The Economist 2013b, Ethirajan 2013), although they have denied any involvement. In addition, the same groups or allies have been accused of attacking activists, bloggers and online activists who they label 'atheists'. Several so-called 'atheist bloggers' and journalists have been murdered or imprisoned and newspapers and television channels have been shut down by the government (HRW 2013, Tripathi 2014). In addition, Islamist groups including Jamaat-e-Islami, Islami Chatra Shibir and Hefazote-Islam have been in conflict with members of the security forces, most notably in late February and early May 2013, and there have been numerous deaths of activists and some members of the security forces (The Economist 2013b).

The next two sections analyse discourses about the Shahbagh protests and the events of Shapla Chottor.

\section{Shahbagh}

On 5 February 2013, the secretary general of Jamaat-e-Islami, Abdul Quader Mollah, was found guilty of participating in and aiding the murder and rape of unarmed civilians by the ICT. He was sentenced to life imprisonment, to the surprise of many who had expected a death sentence. As he left the tribunal, Mollah flashed a triumphant 'V-sign', which was seen by some as a celebration of having avoided the death penalty. The verdict led activists and bloggers to call for protests demanding the death sentence for Mollah and people began to gather at Shahbagh, a road junction in Dhaka (Murshid 2013: 13). Jamaat-e-Islami and its student wing threatened to attack the protest and were then 
blamed for the murder of a prominent blogger and activist (Murshid 2013: 14). Subsequently, the protesters, who were named after the place, 'Shahbagh', adopted a wider set of demands linked to the trial, but also explicitly in opposition to Jamaat-eIslami (Ahmed 2013).

The protest at Shahbagh was peaceful and law enforcement agencies allowed the protest to continue, although some protesters were hostile to Awami League politicians who came to speak to the crowds (Hassan 2013, Quayum 2013, Anam 2013). Shahbagh seems to represent a contradictory secular progressive movement that seeks to usher in a new form of popular secular politics, and at the same time, make reference to the 'spirit of 1971', a nostalgic attachment to the Liberation War. For some, the war is still not over and the impunity of criminals from 1971 have to be tackled once and for all. The demand for the death penalty among Bangladesh's liberals is an example of this contradiction (Zeitlin 2013).

Like the tribunal, Shahbagh elicits a range of views among British Bangladeshis. Protests in solidarity with Shahbagh were held around the world. When protests sympathetic to Shahbagh were held at Altab Ali Park in east London, counter protests led to ugly scenes (Cohen 2013). Attitudes about the role of religion in politics and nationalism and Bangladeshi party politics divide Bangladeshis in London as they do elsewhere. What is different in London is the relative influence of Jamaat-e-Islami and other Islamist groups.

Among supporters of Shahbagh, the protests are considered politically neutral and a good example of peaceful protest:

Shahbagh started with Qader Mollah's V-sign. This was an important movement, aimed to sort out corruption. It was a neutral and non-political movement, which was for creating an open society and they wanted an independent country. They wanted trial, justice and carried out a peaceful protest. Bangladesh can undertake peaceful protest, an example to the rest of the countries (male, 33, migrated to London as a child).

31 Some British Bangladeshis, although they were inclined to support the Shahbagh protests, found the protests and counter protests rather confusing, and felt that the demands for hanging by Shahbagh protesters were disturbing.

I went to Altab Ali Park when there were two different demonstrations. The Shahbagh supporters on one side and the Jamaat on the other side. I got confused at people coming together demanding hanging. I also found some of the images coming from the Shahbagh movement very disturbing-kids saying we want hanging-this was indoctrination. There were both positive and negative images. I would feel more comfortable if they were calling for justice and not hanging (female, 38, born in Bangladesh).

Others utterly rejected the reasoning, methods, politics and ethics of Shahbagh, calling it the 'most stupid movement in Bengali history, ever' (male, 32, born in London). These views are echoed on the websites established in London shortly after the emergence of Shahbagh, seemingly to directly challenge it. This is the 'SaveBangladesh' website's explanation about Shahbagh:

The 'Shahbag' movement has been compared to Egypt's Tahrir Square. In Tahrir, they called for freedom and democracy, in Shahbag, an area in Dhaka, 'protestors' are demanding the death penalty and banning of political parties. They began their protest because one of the accused, Abdul Qader Mollah, was not given the death sentence. As a result of the protest, the government rushed through legislation to overturn the sentence to a death penalty. This 'movement' has the backing of the government. This is a Maoist, Cultural Revolution. You only need to look at the fact 
that Shahbag 'protestors' are allowed to protest by the police, while the very same police have killed and prevented those protesting against what is there for all to see: grave injustice (Save Bangladesh 2013b). The discourses correspond with different iterations of the imagined community of Bangladesh. The Awami League and participants in the Shahbagh protests imagine a Bangladesh that does not include Islamists and forces that did not support the liberation struggle. Shahbagh enjoyed widespread support in Bangladesh in early 2013, while in London Islamist narratives were relatively more influential (The Economist 2013c). Analysis of social media use during the Shahbagh protests illustrates the extent to which British-based users of Twitter opposed the Shahbagh movement while Bangladesh and US-based users were generally more supportive of the movement (Analysing Social Network Blog 2013). Interpretations of events in 'Shapla Chottor' on 6 May illustrate this powerfully.

\section{Shapla Chottor}

In April 2013 a conservative Islamic group called Hefazot-e-Islam gave Sheikh Hasina's government a list of 13 'demands' (Mustafa 2013). They gave the government an ultimatum of three weeks to implement the demands, threatening to lay siege to Dhaka and overthrow the government if the demands were not met. The theme of many of the demands is for a more central role for Islam in the country's constitution, education system, media, society and law. There are also appeals for protection for Islamic scholars and madrassa students and a demand to declare the Ahmadiyya minority as non-Muslims. Several of the demands directly or indirectly referenced Shahbagh, demanding: an end to 'candle lit vigils', the punishment of atheists and 'anti-Islam bloggers'.

The Hefazot-e-Islam movement's demands fall into four categories. The first is for a greater prominence of a particular conservative interpretation of Islam in society and politics, including specific reference to punishing 'atheists', blasphemers, and people involved in Shahbagh. This also includes specific reference to gender relations, the education system, NGOs, the media, public sculptures, and Christian missionaries. The second makes reference to the perceived persecution of Islamic scholars and madrassa students. The movement is said to originate in Quomi madrassas, religious schools that are independent from the state. The third category of demand distinguishes the interpretation of Islam of the Hefazot-e-Islam movement from that of the persecuted Ahmadiyya minority in Bangladesh who they demand be officially declared non-Muslims by the government. The fourth category makes specific reference to Shahbagh, which they are clearly opposed to. The categories range from the desire for a greater role for religion in the state, to the protection of religious scholars from attack, and finally to identifying two particular groups of people as enemies of the Hefazot-e-Islam movement: 
Ahmadiyyas and protesters at Shahbagh (Daily Star 2013a). The Hefazot-e-Islam movement is therefore seen as a counter reaction to the Shahbagh protests. The imagined community of Bangladesh promoted by this movement is one without Ahmadiyyas, and without secular political groups.

Facebook, Twitter and sometimes YouTube accounts that were set up in spring 2013. Immediately, the events were labelled a 'massacre' and 'genocide' by British-based internet activists using websites and social media. Indeed, some of these websites and social media accounts appear to have been set up specifically to publicise and cover the events of 5 and 6 May. Many of them contain specific references to Islam, construct political events in Bangladesh as an attack on Muslims and appeal to all Muslims to join their campaign. There is an explicit attempt to create an alternative narrative of events from the mainstream media. The Feb28 website includes the following description:

28 February 2013 marked the day on which the people of Bangladesh rose up against the Awami League regime in an effort to challenge its brutality and viciousness towards Muslim citizens of Bangladesh and in particular Muslims and Islamic scholars. The Feb28 Justice for Bangladesh movement came about in response to this escalating crisis that has engulfed Bangladesh.

It aims to expose the tyranny and anti-Islamic hatred of the oppressive Awami League regime and is dedicated to bringing you fresh and unbiased news on the struggle of the Bangladeshi people (Feb28 2013b).

These are good examples of the elastic orthodoxy of Islamists. Using the local orthodoxy, these accounts construct the Awami League government as an 'atheist' movement attacking Muslims in general. A Twitter account called '@Shapla_Chottor' was set up on 5 May and calls for revolution in Bangladesh, attacks Sheikh Hasina and the Awami League, and has the descriptor 'Raise your voice against the atheist'. Hasina is described in tweets from @Shapla_Chottor as a 'non-Muslim' and Sheikh Mujib as a 'Hindu'. Responses to these accounts included tweets such as: "This is a time for Muslims no matter who they are to unite" \#opbangladesh \#feb28info" specifically referencing the Feb28 website. Immediately before the events of 5 and 6 May, social media accounts from London were calling for revolution, predicting trouble and launching a denial of service attacks on Bangladeshi government and press websites. On 4 May, publicising this, OpBangladesh 
tweeted: 'Govt of Hasina, be afraid... Be VERY afraid, We give you a chance to take your wealth \& run a way. \#OpBangladesh' along with the following picture:

Figure 1: 'International Wake-up call's

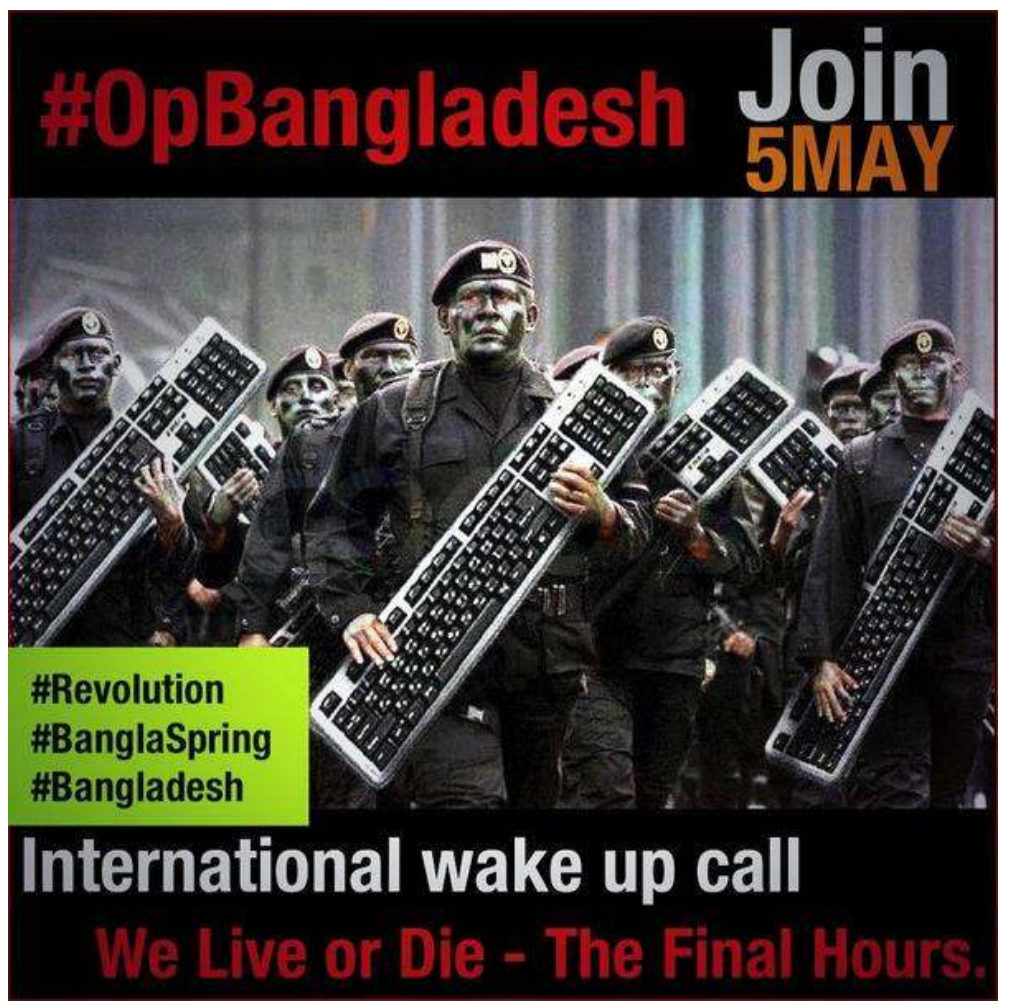

In the days after 5 and 6 May, social media was used extensively, with hundreds of videos and photos uploaded; there were further calls for revolution in Bangladesh and appeals to activists and media to either join their campaign or publicise the violence occurring in Bangladesh. The Feb28 website calls Sheikh Hasina 'lady Hitler', in part of what appears to be a coordinated campaign to label Sheikh Hasina and the Awami League as 'fascists'.

The British websites and social media accounts draw on a similar set of discourses to challenge the dominant narratives about Bangladesh. They promote an Islamist or Jamaat-e-Islami interpretation of events, are very hostile towards the Awami League, and reject dominant narratives about current events in Bangladesh and 1971. Using the hashtags \#Blacknight, \#BanglaSpring, \#SaveBangladesh and \#LadyHitler, a chorus of mainly British voices waged a cyber campaign to challenge secular and Awami League narratives. They have a particular discourse in common, one in which the Hefazot-eIslam protesters were peaceful, religious victims of a 'fascist' 'secular fundamentalist' Awami League who had murdered them in their thousands (the numbers 2,000-3,000 are regularly cited on these websites) and tried to destroy the evidence (Brethren of the Black Lotus 2013). Dominant discourses are attached and new mythologies are created through this work.

43 Hefazot-e-Islam clearly have support among British Bangladeshis, and this was reflected in the interviews:

Hefazot movement is the sentiment of peace loving Islamic sentiment but the western world will not accept it' (male, 29, born in Bangladesh). 

repeated by interviewees:

What do you think about the Hefazot-e-Islam movement?

They have the right to protest, I agree with about 11 of their 13 points. They were massacred terribly. They captured the public imagination. We lack sophisticated Islamic leaders able to guide our people through issues of social justice in a way that brings everyone together. I wish Hefazot safety and improvement (male, 32, born in London).

Another respondent reported on their family in Bangladesh's support for Hefazot-e-Islam (despite not 'practicing Islam very well'). She also reported the claim that 2,000-3,000 people died at Shapla Chottor. This respondent believed that there was Indian involvement in the events and explicitly juxtaposed Hefazot-e-Islam with Shahbagh :

I had reports that when Hefazot movement started many villages in Bangladesh were so happy that people bought up watermelons to celebrate by eating together and this caused a shortage of watermelons.

When Hefazot started I started to feel hopeful. They started to take on the government. Hefazot is not against women's leaderships as such as they have voted in elections for the two women in the past.

My family in Bangladesh is supportive of Hefazot and they hate Shahbagh. Even if they do not practise Islam very well they love and support the Hefazot for the way they stood up against the psychopath Hasina.

3,000 murdered-I know people who were personally there. When government say 11 people died I know people who were there, definitely, 2,000-3,000 people died. Some of the Bangladeshi police were given instructions in Hindi-Indians were there. The Indian Army was brought in as a back up. Hasina is a razakar to India (female, 28, born in London).

A few respondents indicated opposition to the demands of Hefazot-e-Islam, and described them as rather politically naïve. Some press reports describe the movement as being a front for, or having been manipulated by, Jamaat-e-Islami:

What do you think about the Hefazot-e-Islam movement?

It is laced with some unfortunate demands, and sweeping accusations about its position has meant that it's become complicated, and perhaps the movement is not really ready for the political arena (male, 28, came to UK as a child).

There was no hostility or anger towards Hefazot-e-Islam expressed by the interviewees. The sample is not representative, but it illustrates a difference from the feelings of many 'Western' and Bangladeshi journalists and analysts and it is different from mainstream opinion in Bangladesh, which still largely subscribes to the dominant discourse described earlier. Press reports in 'Western' and Bangladeshi English language press present Hefazot-e-Islam as a dangerous, atavistic movement that will send Bangladesh back to the 'dark ages', mainly due to their stance on women (Mustafa 2013, Daily Star 2013b).

In the interviews and in blog postings, the Hefazot-e-Islam movement was juxtaposed with Shahbagh, the two being seen as representing rural and urban constituencies and different socio-economic groups and as being exemplary of the divide in Bangladeshi politics and society. In an article on the Kichuri blog, the author 'Londoni' (British Bangladeshi) writes about the contested narratives about Hefazot-e-Islam and their 13 point demands. The author specifically critiques mainstream media coverage of events but offers a more nuanced interpretation than the simple divide between 'secular' Shahbagh and 'conservative' Hefazot-e-Islam:

Such demands have already been seized upon by people like the Guardian's Jason Burke. His recent report on the Long March describes the Shahbag protestors as 
'young moderates', moderates who call for death penalties and banning of political parties, contrasting them favourably to the Long Marchers. Mr Burke, who has covered Afghanistan and Pakistan with some nuance in the past, also fails to mention the controversy and scandal that Bangladesh's International Crimes Tribunal is embroiled in (Londoni 2013). relationships between British Bangladeshis and Bangladesh. The campaigns on social media were aimed mainly at an English speaking, educated audience and encouraged people to apply their London-learned Islamist subjectivity to current events in Bangladesh. Constructing events in Bangladesh as an attack on Muslims presents events as a conflict between atheists and Muslims. It also invoked the mentality of the "War on Terror' years when British Bangladeshis felt that they were a suspect community because they were Muslims. Perhaps this was an element that re-engaged some British Bangladeshis with Bangladeshi politics through a certain lens, as the following interviewee explains, speaking about the violence of 6 May:

Those of us who care were heartbroken at the massacre. I think it puts a lot of people off caring about the people there. But it also provides a point of access for people losing their roots (male, 32, born in London).

ust as 9/11 led to a surge of interest in the meaning and role of Islam in a soul searching British Bangladeshi population (Glynn 2002), the ICT and events in Bangladesh have led to a renewed interest in 1971, the birth of Bangladesh and Bengal's history in general. The sudden emergence of new websites, social media accounts and political activity is evidence of this. Both surges in interest led to conscious attempts to construct alternative narratives to those of the mainstream media and government (Ahmad 2006). This is explicitly mentioned in several of the websites and it is an interesting example of transnational political activity, what Glick Schiller and Fouron (2001) call 'long distance nationalism', the feeling of belonging and involvement in the nation, for people who do not live or have citizenship in that nation, through transnational connections.

\section{Conclusion}

Recent events in Bangladesh have captured the imaginations of British Bangladeshis. Interpretations of events differ amongst political and religious groups that have contrasting views of who is the victim and who is the aggressor. Bengali nationalists, Awami League supporters, secular and left wing groups see the ICT as the legitimate conclusion of the Liberation War. Bangladeshi nationalists, represented by the BNP hold views about the ICT, Shahbagh and Hefazot-e-Islam that are similar to Islamist interpretations, such as those of Jamaat-e-Islami. These may be influenced by ideology, different histories and also the political position they hold in opposition to the governing party. These interpretations of events, that are influential in London and appear to be influenced by Islamists, see the Awami League and mainstream media as persecuting Islamists in Bangladesh and attacking Islam itself.

The extent of the influence of Islamist groups among British Bangladeshis in London and the reasons behind the phenomenon are unclear. One view is that this is a legacy of the emergence in the last twenty-five years of Islam as an important source of identity among British Bangladeshis. Islamist approaches represent an 'alternative modernity', offering progress from the traditions of the village that is explicitly critical of 'Western modernity'

South Asia Multidisciplinary Academic Journal, 9 | 2014 
(Zeitlyn 2014). Some of the subjectivities and methods of resisting Islamophobia during the 'War on Terror' years have been brought to bear in response to events in Bangladesh. The distrust of and critique of mainstream media and government discourses bears striking similarities with those of the 'War on Terror' years and draws upon some of the same discourses challenging the misrepresentation of Muslims and Islam in the media. This is a good example of the elastic orthodoxy that DeHanas (2013b) describes, where local orthodoxies are used to interpret developing events in other places. Many British Bangladeshis challenged the UK and US governments' 'War on Terror' in the years after 9/11 and some have used the same methods to challenge dominant discourses about recent events in Bangladesh (Begum \& Eade 2005).

Another type of interpretation is that the deployment of 'Western' notions of due process, human rights and international law by Human Rights Watch (2013b), Bergman (2012), The Economist (2012) and lawyers hired by the defendants in the ICT, have successfully critiqued the ICT. In addition, Sarmila Bose's (2011a, 2011b) work on 1971 has challenged the dominant narratives about the war. These critiques have gained credibility among British Bangladeshis. Certainly a wider range of media and comment on events in Bangladesh, often with transnational reach, has complicated narratives on/in Bangladesh. The British Bangladeshis behind the transnational internet activism have drawn upon these sources to bolster their critiques of dominant discourses and challenge the shared mythology of nationalism(s) in Bangladesh.

Transnational political activity plays a key role in critiquing nationalism(s) in Bangladesh. Broad, occasional interest piqued by key events is turned, perhaps temporarily, into narrow, focused and regular activism through these campaigns. These efforts and recent events have seen a renewed interest in 1971 and contemporary Bangladeshi politics among British Bangladeshis.

\section{BIBLIOGRAPHY}

Ahmad, Fauzia (2006) 'British Muslim Perceptions and Opinions on News Coverage of September 11', Journal of Ethnic and Migration Studies, 32(6), pp. 961-82.

Ahmed, Rahnuma (2013) 'Youth Uprising at Shahbagh, Reclaiming Ekattur: Fashi, Bangali', New Age, 15 February, http://www.newagebd.com/detail.php? date=2013-02-15\&nid=40086\#.UR5AxaUtxWU (accessed 20 June 2014).

Alam, Shahidul (2013) 'A 40-Year Quest for Justice', New York Times, 28 February.

Ali, Mahmud (2010) Understanding Bangladesh, London: Hurst.

Analysing Social Network Blog (2013) ‘\#shabagh vs \#savebangladesh’ 26 February, http:// technologyandsocialparticipation.blogspot.co.uk/2013/02/shahbag-vs-savebangladesh.html (accessed 13 February 2014).

Anam, Tahnima (2013) 'Shahbag Protesters Versus the Butcher of Mirpur', The Guardian, 13 February, http://www.guardian.co.uk/world/2013/feb/13/shahbag-protest-bangladesh-quadermollah (accessed 20 June 2014). 
Anderson, Benedict (2006) Imagined Communities, London: Verso, [1983].

Begum, Halima; Eade, John (2005) 'All Quiet on the Eastern Front? Bangladeshi Reactions in Tower Hamlets', in Tahir Abbas, (ed.), Muslim Britain, Communities Under Pressure, London: Zed Books, pp. 179-93.

Bergman, David (2012) 'Has the Economist Got it Right?', South Asia Journal Blog, http:// southasiajournal.net/2013/03/has-the-economist-got-it-right/ (accessed 20 June 2014).

Bergman, David; Foyez, Ahammad (2013) '24 'Hefajat Rally' Deaths Identified', New Age, 3 June, http://www.newagebd.com/detail.php?date=2013-06-03\&nid=51470 (accessed 20 June 2014).

Bose, Sarmila (2011a) Dead Reckoning: Memories of the 1971 Bangladesh War, London: Hurst and Co. Bose, Sarmila (2011b) 'The Question of Genocide and the Quest for Justice in the 1971 War', Journal of Genocide Research, 13(4), pp. 393-419.

Brethren of the Black Lotus (2013) 'Bangladesh: Who Told You that the Revolution Would be Televised?', Ceasefire Magazine, 13 July, http://ceasefiremagazine.co.uk/bangladesh-toldrevolution-televised-massacre/ (accessed 20 June 2014).

BX (2013) ‘Three Bangladeshes intertwined', The Kichuri Blog 17 February, http:// www.khichuri.org/three-bangladeshe-intertwined/ (accessed 20 June 2014).

Cohen, Nick (2013) 'The Agonies of Bangladesh Come to London', The Observer, 17 February, http://www.guardian.co.uk/commentisfree/2013/feb/17/bagladeshi-protests-reflected-londonseast-end (accessed 20 June 2014).

Curlin, George; Lincoln, Chen; Hussain, Sayed Babur (1976) 'Demographic Crisis: The Impact of the Bangladesh Civil War (1971) on Births and Deaths in a Rural Area of Bangladesh', Population Studies, 30(1), pp. 87-105.

Daily Star. 2013a. 'Hefajat Demands', 6 April, http://www.thedailystar.net/beta2/news/hefajatdemands/ (accessed 20 June 2014).

Daily Star. 2013b. 'Hefajat Strikes Horror’, 6 May, http://www.thedailystar.net/beta2/news/ hefajat-strikes-horror/ (accessed 20 June 2014).

DeHanas, Daniel Nilsson (2013a) 'Of Hajj and Home: Roots Visits to Mecca and Bangladesh in Everyday Belonging', Ethnicities, 13(4), pp. 457-74.

DeHanas, Daniel Nilsson (2013b) 'Elastic Orthodoxy: The Tactics of Young Muslim Identity in the East End of London', in Nathal Dessing, Nadia Jeldtoft, Jorgen Nielson \& Linda Woodhead (eds.), Everyday Lived Islam in Europe, Farnham: Ashgate.

Department for Education (2014) GCSE and equivalent results in England, 2012 to 2013 (revised), https://www.gov.uk/government/publications/gcse-and-equivalent-results-in-england-2012to-2013-revised.

Eade, John; Garbin, David (2002) 'Changing Narratives of Violence, Struggle and Resistance: Bangladeshis and the Competition for Resources in the Global City', Oxford Development Studies, 30 (2), pp. 137-49.

The Economist. 2007. 'From Brick Lane to the Fast Lane', 25 October, http://www.economist.com/ node/10024877 (accessed 20 June 2014).

The Economist. 2012. 'The Trial of the Birth of a Nation', 15 December, http:// www.economist.com/news/briefing/21568349-week-chairman-bangladeshs-internationalcrimes-tribunal-resigned-we-explain (accessed 20 June 2014). 
The Economist. 2013a. 'Another Kind of Crime', 23 March, http://www.economist.com/news/ leaders/21573990-bangladeshs-war-crimes-tribunal-sullying-its-judicial-and-political-systemsanother-kind?zid=306\&ah=1b164dbd43b0cb27ba0d4c3b12a5e227 (accessed 20 June 2014).

The Economist. 2013b. 'A nation divided', 9 March, http://www.economist.com/news/ asia/21573150-flawed-tribunal-opens-old-wounds-and-threatens-bangladeshs-future-nationdivided (accessed 20 June 2014).

The Economist. 2013c. 'The Dhaka-East London axis', 3 March, http://www.economist.com/blogs/ erasmus/2013/03/islamism-britain-and-bangladesh?fsrc=scn\%2Ftw_ec\% 2Fthe_dhaka_east_london_axis (accessed 20 June 2014).

Ethirajan, Anbarasan (2013) 'Bangladesh Minorities 'Terrorised' after Mob Violence', BBC News, 9 March, http://www.bbc.co.uk/news/world-asia-21712655 (accessed 20 June 2014).

Feb28 (2013a) 'Bangladesh ICT has made 'Mockery of International Law', http://feb28.info/learnmore/find-out-more/legal/799-bangladesh-ict-has-made-mockery-of-international-law (accessed 13 February 2014).

Feb28 (2013b) ‘FEB28 Justice for Bangladesh' http://feb28.info/index.php/about (accessed 13 February 2014).

Gardner, Katy; Shukur, Abdus (1994) 'I'm Bengali, I'm Asian and I'm Living Here: The Changing Identities of British Bengalis', in Roger Ballard (ed.), Desh Pardesh, London: Hurst and Co, pp. 162-63.

Glick Schiller, Nina; Fouron, Georges (2001) Georges Woke Up Laughing: Long Distance Nationalism and the Search for Home, Durham, NC: Duke University Press.

Glynn, Sarah (2002) ‘Bengali Muslims: the New East End Radicals?', Ethnic and Racial Studies, 25(6), pp. 969-88.

Glynn, Sarah (2006) 'The Spirit of '71: How the Bangladeshi War of Independence has Haunted Tower Hamlets', Institute of Geography Online Paper Series: GEO-020, Edinburgh: School of Geosciences.

Glynn, Sarah (2012) ‘Muslims and the Left: An English Case Study', Ethnicities, 12(5), pp. 581-602.

Gupta, Swarupa (2007) 'Samaj, Jati and Desh: Reflections on Nationhood in Late Colonial Bengal', Studies in History, 23(2), pp. 177-203.

HRW (Human Rights Watch) (2013) 'Bangladesh: Crackdown on Bloggers, Editors Escalates', 14 April, http://www.hrw.org/news/2013/04/15/bangladesh-crackdown-bloggers-editors-escalates (accessed 20 June 2014).

Hussain, Delwar (2007) 'Globalisation, God and Galloway: The Islamicisation of Bangladeshi Communities in London', Journal of Creative Communications, 2(1\&2), pp. 189-217.

Hylland, Eriksen (1993) Ethnicity and Nationalism: Anthropological Perspectives, London: Pluto Press. Islam, M. Saidul (2011) “Minority Islam' in Muslim Majority Bangladesh: The Violent Road to a New Brand of Secularism', Journal of Muslim Minority Affairs, 31(1), pp. 125-41.

Jalil, M. Abdul; Rahman, Muhammad Khalilur (2011) 'Human Rights Violation and Political Persecution in Bangladesh: The Current Scenery', Asian Culture and History, 3(1), pp. 46-53.

Jivraj, S.; Khan, O. (2013) Ethnicity and Deprivation in England: How Likely are Ethnic Minorities to Live in Deprived Neighbourhoods? Centre on Dynamics of Ethnicity (CoDE), Manchester: The University of Manchester. 
Lewis, David (2011) Bangladesh: Politics, Economy and Civil Society, Cambridge: Cambridge University Press.

Linton, Suzannah (2010) 'Completing the Circle: Accountability for the Crimes of the 1971 Bangladesh War of Liberation', Criminal Law Forum, 21, pp. 191-311.

Londoni (2013) 'The Long March to Another Contested Bangladeshi Narrative', Kichuri Blog, 22 April, http://www.khichuri.org/the-long-march-to-another-contested-bangladeshi-narrative/ (accessed 13 February 2014)

Murshid, Nadine (2013) 'The Shahbag Uprising War Crimes and Forgiveness', Economic \& Political Weekly, 48(10), pp. 13-5.

Mustafa, Sabir (2013) 'Hefazat-e Islam: Islamist coalition', BBC News Asia, 6 May http:// www.bbc.co.uk/news/world-asia-22424708 (accessed 20 June 2014).

Odhikar (2013) 'Assembly of Hefazate Islam Bangladesh and Human Right Violations, Fact Finding Report', Dhaka: Odhikar, http://odhikar.org/documents/2013/FF_Report_2013/

Hefazat_e_islam/Fact\%20finding_Hefazate\%20Islam_English.pdf (accessed 13 February 2014)

Office for National Statistics (ONS) (2012) 'Ethnicity and National Identity in England and Wales 2011', http://www.ons.gov.uk/ons/rel/census/2011-census/key-statistics-for-local-authoritiesin-england-and-wales/rpt-ethnicity.html (accessed 20 June 2014)

Ofsted (2004) Achievement of Bangladeshi Heritage Pupils, London: OFSTED.

Østergaard-Nielsen, Eva (2003) ‘The Politics of Migrants' Transnational Political Practices', International Migration Review, 37(3), pp. 760-86.

Platt, Lucinda (2009) Ethnicity and Child Poverty, Department for Work and Pensions Research Report No 576, London: Department for Work and Pensions.

Quayum, Nayma (2013) 'Is Bangladesh's Shahbag the Next Tahrir Square?' World Policy Journal Blog , 21 February, http://www.worldpolicy.org/blog/2013/02/21/bangladesh\%E2\%80\%99s-shahbagnext-tahrir-square (accessed 20 June 2014).

Save Bangladesh. (2013a). 'The ICT', http://www.savebangladesh.org.uk/the-ict-bd/_accessed on 13 February 2014).

Save Bangladesh. (2013b). 'The Reality of Shahbagh', http://www.savebangladesh.org.uk/thereality-of-shahbag-bd/ (accessed 13 February 2014).

Sayyid, Bobby (2000) 'Beyond Westphalia: Nations and Diasporas, the Case of the Muslim Umma', in Barnor Hesse (ed.), Un/Settled Multiculturalisms, London: Zed Books.

Tripathi, Salil (2014) ‘Blogging, Blasphemy and Bans', Index on Censorship, 43(1), pp. 119-22.

Vertovec, Steven (1999) ‘Conceiving and Researching Transnationalism', Ethnic and Racial Studies, 22(2), pp. 447-62.

Zeitlin, Arnold (2013) ‘Bewildered by Bangladesh', South Asia Journal, Issue 8, Spring 2013, http:// southasiajournal.net/2013/04/bewildered-by-bangladesh/ (accessed 13 February 2014).

Zeitlyn, Benjamin (2014) 'The Making of a Moral British Bangladeshi', Journal of Moral Education, 43(2), pp. 198-212. 


\section{NOTES}

1. I wish to acknowledge the role of Dr. Muhammad Ahmedullah in this paper. He contributed significantly to this research by conducting the interviews and developing the analysis presented here.

2. The name Hefazot-e-Islam (protector of Islam) is also transliterated as Hifazat, Hefazat, Hefajat, Hefajote, and in numerous other ways.

3. Gulam Azam and Delwar Hussain Sayedee are defendants in the ICT. Both are leaders of Jamaat-e-Islami and both have been found guilty of crimes against humanity by the ICT.

4. A post Liberation War agreement between India, Bangladesh and Pakistan.

5. Source: https://twitter.com/OpBangladesh/status/330690945404260352 (accessed

20/06/2014).

\section{ABSTRACTS}

This paper analyses responses in London to the International Crimes Tribunal in Bangladesh and protests associated with it in 2013. Based on analysis of websites, social media and interview material, it examines interpretations of contemporary events in Bangladesh. The article makes no claims to any privileged information or 'truth' about these events. Instead, it argues that interpretations of events in Bangladesh by Bangladeshis in London differ from those in Bangladesh. Recent events in Bangladesh have led to an increase in transnational political activism among some British Bangladeshis. In London there have been concerted attempts to challenge dominant discourses about Bangladesh's Liberation War and contemporary politics. In many cases these are related to or inspired by Islamic political movements that have become influential among British Bangladeshis.

INDEX

Keywords: Bangladesh, International Crimes Tribunal, 1971, Shahbagh, transnationalism

\section{AUTHOR}

\section{BENJAMIN ZEITLYN}

Lecturer in International Education and Development, Centre for International Education, University of Sussex, Brighton, UK 